\title{
SIMULATION-BASED TRAINING IN FIRE PREVENTION AND FIRE-FIGHTING OF SCAVENGE AIR RECEIVERS FIRES
}

doi: $10.2478 /$ czoto-2020-0013

Date of submission of the article to the Editor: 19/08/2019

Date of acceptance of the article by the Editor: 20/02/2020

Prof. Leszek Chybowski ${ }^{1}$ - orcid id: 0000-0003-0245-3946

Seweryn Strojecki ${ }^{2}$ - orcid id: 0000-0003-1516-3374

Włodzimierz Markiewicz ${ }^{3}$ - orcid id:0000-0002-2283-3375

${ }^{1}$ Maritime University of Szczecin, Poland, I.chybowski@am.szczecin.pl

${ }^{2}$ Carnival Corporation \& plc, USA, seweryn1186@gmail.com

${ }^{3}$ BP plc, United Kingdom, tolek74@gmail.com

Abstract: This article presents topics concerning fire hazards during the use of lowspeed diesel engines in marine vehicles. The causes and effects of fires in the spaces of scavenge air receivers in marine diesel engines are presented. Methods to prevent and fight these fires are shown, including the operating procedures required from ship engine room operators. The possibility of training personnel to apply the abovementioned procedures during operation using simulations of a Kongsberg MC-90 IVship engine room is presented. Simulations were conducted which included a fire in a scavenge air receiver occurring during the operation of a MAN B\&W 5L90MC main engine, with loads corresponding to $50 \%$ and $100 \%$ of the machine's recommended setting.

Keywords: fire safety, marine diesel engine, scavenge air receiver, engine room simulator, safety training

\section{INTRODUCTION}

Ship engine rooms have high explosion and fire risks because they contain all three of the factors necessary to initiate combustion: combustible materials (fuels, lubricating oils, oil waste), oxygen sources (ventilation systems, starting air systems, engine charging systems), and heat sources (exhaust gas discharge manifolds, potential exhaust gas purges to underpiston spaces, friction processes) (Bistrović et al., 2017; Cieślak et al., 2000; Gawdzińska et al., 2015; Krystosik-Gromadzińska, 2016, 2019; Ubowska and Szczepanek, 2016). A fire is an uncontrolled, spontaneous combustion of materials (Gawdzińska et al., 2017), whereas an explosion is a rapid release of large amounts of energy, which is usually accompanied by a rapid increase in temperature and pressure, radiation emission (e.g., lightning, sparks), and acoustic waves (e.g., sound, bang). Explosions are caused by violent physical phenomena (e.g., explosions of gas tanks or tyres (Chybowski et al., 2015,Karliński et al., 2019; 
Karliński et al., 2014b, 2014a)), and rapid exothermic chemical reactions (e.g., combustion). The release of energy usually results in repeated environmental damage due to mechanical impacts and repeated fires and explosions (Chybowski et al., 2018; Kaczyński et al., 2019; Ulewicz and Mazur, 2013; Ulewicz et al., 2019). Both fires and explosions pose huge threats to the machinery crew, in particular those in marine engine rooms (Chybowski et al., 2019; Chybowski and Kazienko, 2019; Laskowski et al., 2015).

Fires can occur in scavenge air receivers of marine engines (Strojecki, 2011). Scavenge air receivers in slow-running engines are high-capacity tanks that are bolted to a cylindrical block, which is open towards air flushing through the engine (Fig. 1). The flushing air is collected in the receiver after passing through a radiator or coolers, depending on the construction.

In the receiver of the flushing air, there are check valves that open under pressure acting from inside the valve body. The position and number of check valves depend on the particular construction, which varies by manufacturer. In the air receiver behind the air cooler, there may also be an air dehumidifier.

There are auxiliary blowers at the flushing air receiver scavenge, whose task is to support the turbocharger and maintain a minimum air pressure in the receiver whenever the engine rotates at a low speed, dynamically accelerates, or during engine start-up. In such situations, the turbocharger cannot generate the appropriate pressure inside the scavenge air receiver due to an insufficient amount of exhaust gases powering it. The scavenge air receiver also has a safety valve (Fig. 2) which is designed to open if the pressure in the receiver exceeds the permissible standard 3.43.8 bar or the pressure specified by the manufacturer.

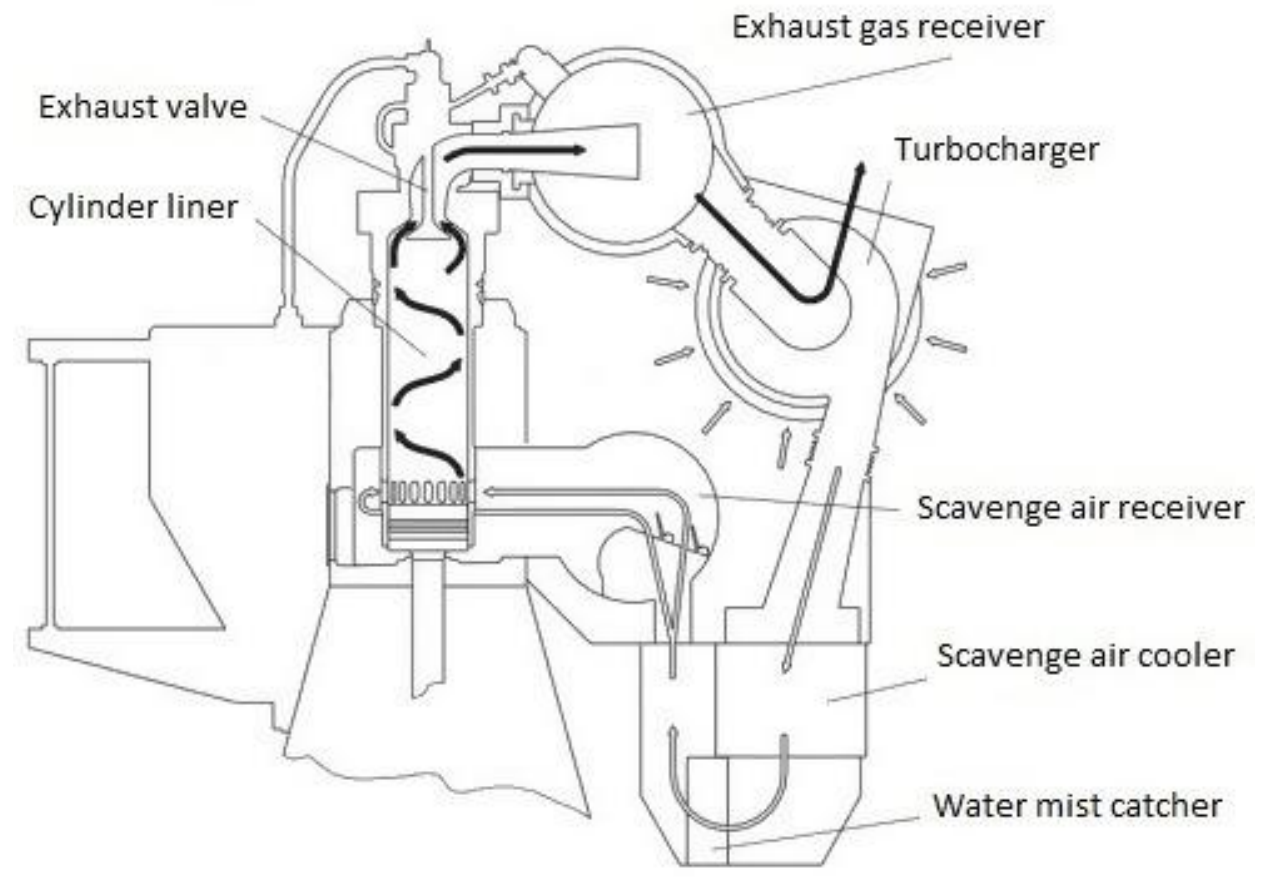

Fig. 1. Scavenge air system

Source: (MAN B\&W Diesel A/S, 2013) 


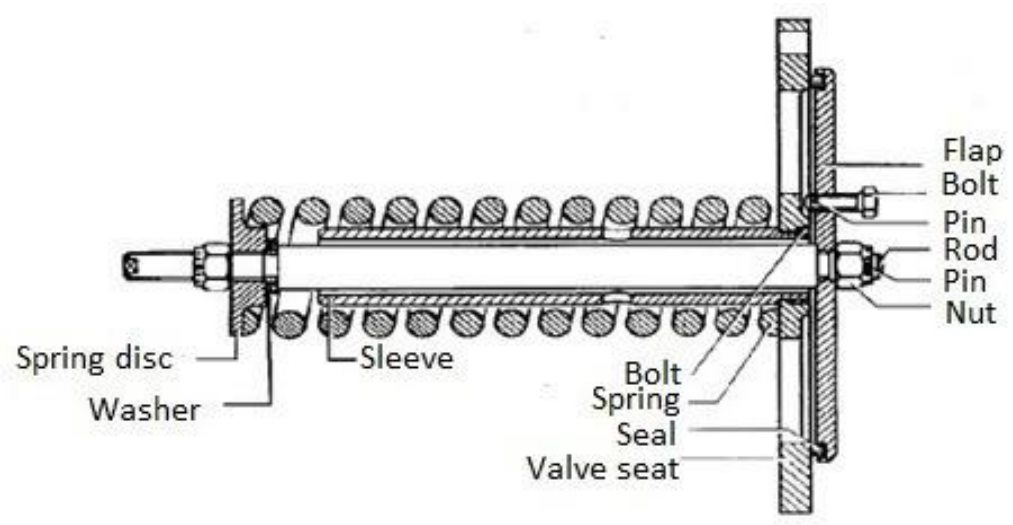

Fig. 2. Safety valve scavenge air receiver

Source: (MAN B\&W Diesel A/S, 2013)

Fires and explosions in the scavenge air receiver are among the most serious failures of marine engines due to the potential consequences and extent of damage. Very often, such situations end tragically, and maritime statistics indicate that many sailors have lost their lives in these situations. Significant material damage can also occur.

\section{CAUSES AND EFFECTS OF FIRES IN SCAVENGE AIR RECEIVERS}

Fires may be caused by the ignition of products scraped off by pistons from cylinder liners and the scavenge air receiver (Fig. 3), such as those from burnt cylinder oil, carbon deposits, oil, etc.

Excess amounts of these products may be deposited due to:

- poor quality fuels, which affect the combustion efficiency,

- poor technical condition of the engine,

- poor condition of the injection equipment, e.g., "pouring" injector, improperly spraying injector,

- excessive overload of the engine or individual cylinders,

- insufficient amount of rinsing air due to a malfunctioning turbocharger,

- obstructed exhaust system due to combustion of residues deposited in the exhaust manifold and on the turbine grate,

- poor condition of the piston rings,

- poor condition of the cylinder liners,

- incorrect delivery timing of the cylinder oil,

- incorrect static setting of injection pumps.

Combined, these factors lead to excessive contaminant deposition in the scavenge air receiverand also pose a fire hazard in the receiver. Oil deposited in the scavenge air receiver gradually carbonizes due to temperature until it reaches the point of combustion due to the compressed air. The ignition of carbon deposits in the scavenge air receiver may be caused by:

- prolonged gas blowing,

- slow combustion in the cylinder due to incorrect fuel spray, incorrect injector tip type (nozzle), or misaligned fuel injection,

- reverse flow of gases through the flushing air vents due to incorrect positioning of the exhaust cam disk or high resistance in the exhaust gas system due to counter-pressure. 


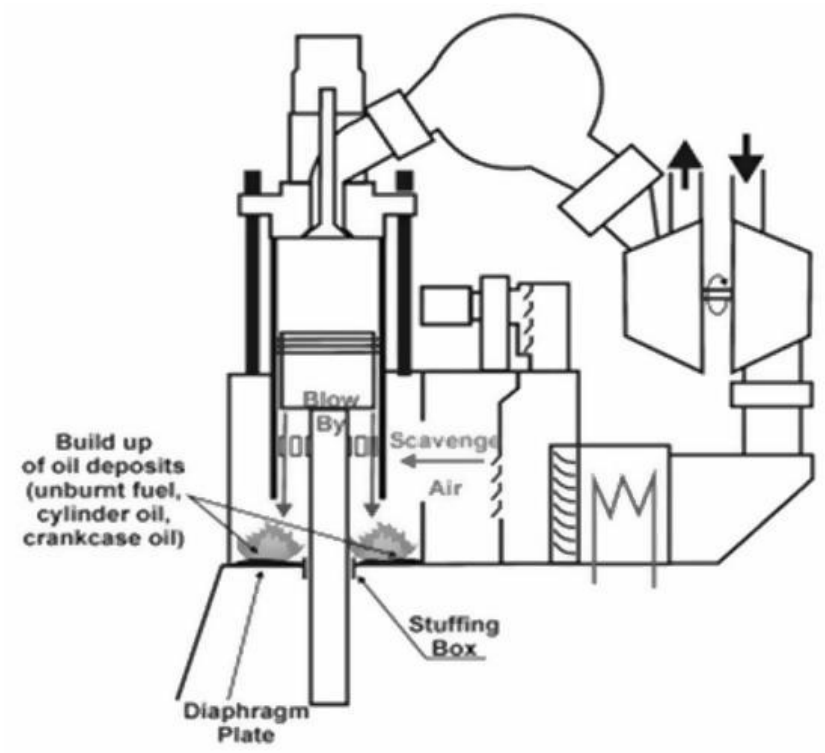

Fig. 3. Initiation of a fire in the underpiston space as a result of exhaust gas blow-by Source: (Marine Diesels, 2011)

Another danger in the scavenge air receiver is the explosion of oil mist, which can occur not only in the crankcase, but also in the scavenge air receiver due to the constant presence of oil in the charging air. Ignition of this mixture may occur, e.g., as a result of the backflow of exhaust gas from the cylinder to the scavenge air receiver, or exhaust gas purging. The gas-air and exhaust gas flow directions depend on the pressure difference. The following condition should be met at all times during the load exchange:

$$
p_{\text {air }}>p_{c y l}>p_{\text {exh }}
$$

where $p_{\text {airls }}$ the charging air pressure, $p_{c y l}$ is the gas pressure in the cylinder, and $p_{\text {exh }}$ is the exhaust gas pressure behind the cylinder.

A fire in the scavenge air receiver in its initial stage is nearly impossible to see because it takes place inside the engine. The signs of a fire in the scavenge air receiver include a drop in engine speed and smoke, as well as an increase in the temperature of exhaust gases, possible turbine stall, and a temperature increase in the scavenge air receiver. A sudden blow will cause smoke, sparks, and flames to be blown out when each of the drainage taps of the receiver is open. Therefore, it is necessary to maintain an efficient drainage system. Due to the risk of an explosion in the crankcase, it is not recommended to stand near its safety valves since flames can rapidly escape the engine housing.

A fire in a scavenge air receiver can lead to very serious consequences, among the most dangerous of which are explosions of the engine crankcase. In addition, a fire in the receiver can cause the piston-cylinder system components to overheat, and also stuffing boxes in crosshead engines. In addition, the hull may be deformed, cracked, or damaged. In the case of significant overheating of the scavenge air receiver walls, it is recommended to check the tension of the tightening screws, as they may loosen due to the high temperature.

After over 100 years of marine engine development, many design solutions have been created and implemented to ensure the safe operation of an engine. This also applies to the protection of charge air reservoirs. 


\section{PREVENTING AND FIGHTING FIRES IN SCAVENGE AIR RECEIVERS}

Passive fire protection is understood to be regular inspections of the scavenge air receiver, its blowing, and cleaning. These activities are performed by the machine crew in accordance with strictly defined procedures and manufacturer recommendations. The main duty of the crew during the scavenge air receiver operation is to maintain the cleanliness of the internal space of the container. In this space, all products collected by the piston from cylinder linings, such as cylinder oil, fuel sludge, oil sludge, etc., accumulate. Replaced contaminants must be removed on an ongoing basis to prevent a fire in the air receiver. For this purpose, at least once per shift, the drain valve on the line connecting the drainage tank with the sewage tank should be opened for a period of several dozen engine revolutions.

Despite the systematic implementation of the above-mentioned procedures, after several months of engine operation, the scavenge air receiver accumulates a layer of sediments that cannot be removed by "blowing." Thus, every 3-6 months, it is necessary to carefully clean the scavenge air receiver to remove sludge and hard carbon deposits.

To ensure that oil sludge from the scavenge air receiver is drained off, thereby reducing the fire risk, it is recommended to (MAN B\&W Diesel A/S, 2013):

- perform daily checks of the drainage pipes while the engine is in motion;

- regularly clean the drainage pipes.

Drainage pipe cleaning should be carried out at regular intervals to prevent blockages in the drainage system. The main drainage pipe and the supply pipe to the drainage tank can be cleaned with air, hot water, or steam while the engine is idle. If valve leakages are suspected, they must be removed and cleaned by hand with the main drainage pipe. When using water or steam, the risk of corrosion of the piston rods must be considered if the valves are leaking.

To prevent the formation of favourable conditions for the self-ignition of coal deposits and the explosion of oil mist in the scavenge air receiver, the following basic operating rules should be closely followed (Strojecki, 2011):

- the technical condition of the engine must be maintained at an appropriate level in accordance with the manufacturer's requirements and normal operation. Specifically, the correct operation of the piston-crankshaft system and the load exchange installation should be checked (Nozdrzykowski \& Chybowski, 2019). The engine should not be operated if the liner and piston rings cylinder are significantly worn out,

- the technical condition of injection equipment, lubrication, and cooling system must be maintained at an appropriate level, and should also be checked to ensure proper regulation,

- under no circumstances should the motor or individual cylinders be overloaded,

- the correct operation of the main engine protection devices must be checked periodically.

If a fire is detected (increase in temperature of the block and tank plates, smoke, increase in the exhaust gas temperature) in the scavenge air receiver, the following actions should be performed immediately (MAN B\&W Diesel A/S, 2013): 
- reduce the speed or stroke of the screw to the "slow" e.g.,"forward" position, and stop the motor automatically or manually after obtaining permission from the navigation bridge,

- if there is a risk of fire spreading into the crankcase, the cooling should not be switched off when the engine stops, and it is recommended that the turntable be switched on to avoid thermal stress on the heated elements,

- switch off the auxiliary blowers,

- stop the fuel supply (stop the pumps),

- stop the oil supply (stop the pumps),

- prepare fire extinguishing equipment forthe scavenge air receiver (do not open the container or crankcase from the side of the fire until the temperature drops below $\left.100^{\circ} \mathrm{C}\right)$,

- remove wet sediment and sludge from all parts of the scavenge air receiver,

- clean the individual rods and bushings, and check their surface condition, alignment, and distortion, then apply an oil film,

- repeat the above steps, but focus on the piston crown and jacket while the engine is running (oil and cooling rein attached). Also check the stuffing box and the bottom of the scavenge air receiver for potential cracks caused by fire.

If, for some reason, the machine crew does not detect any signs of fire in the scavenge air receiver system alarm,an alarm is generated when the temperature in the flushing air reaches $80^{\circ} \mathrm{C}$, and at $120^{\circ} \mathrm{C}$ activates the "Slow down" procedure and reduces the speed or stroke of the screw.

Figure 4 shows the fire-fighting system in the engine scavenge air receiver spaces MAN B\&W. During the fire-fighting process, the system is connected to a valve marked "AT", and its correct position is set. The following extinguishing agents may be used: steam, water mist, or $\mathrm{CO}_{2}$ for fighting with fire in scavenge air receivers.

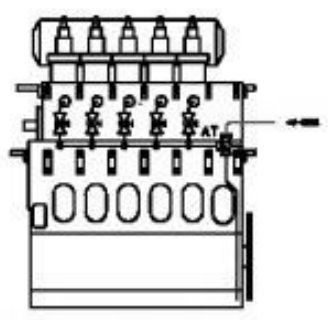

Steam extinguishing

Steam pressure 3-10 bar

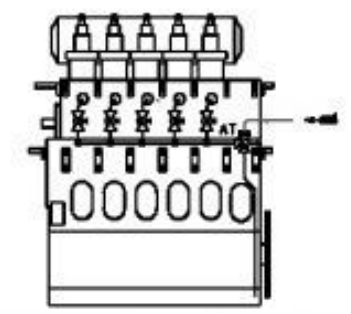

Water mist extinguishing

Fresh water pressure 3.5 bar

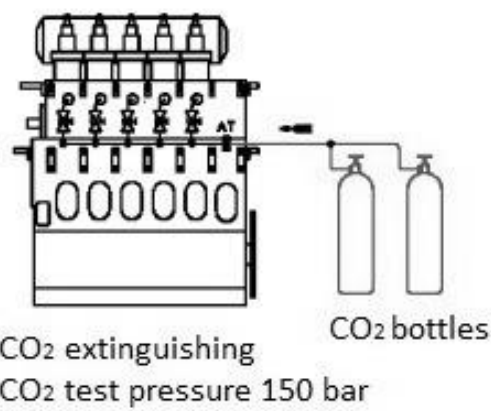

$\mathrm{CO}_{2}$ test pressure 150 bar

Fig. 4. Fire-fighting systems in scavenge air receiver spaces

Source: (MAN B\&W Diesel A/S, 2013)

Depending on the model, the extinguishing agent delivery systems differ slightly in their design. This relationship is easily understandable, since the supply of oil mist or steam must be included in the construction of the extinguishing system of the scavenge air receiver drainage pipe, so that the water collected in the receiver can be drained after the fire is extinguished.

The main difference between these three extinguishing factors is their form of administration. Steam is administered at pressures from 3-10 bar from the main steam system, whereas water mist is applied at minimal pressures 2.5 bar from the fresh water 
system. In this case, the inert gas $\mathrm{CO}_{2}$ should be fed at 150 bar from cylinders designed specifically for fire-fighting in the main engine.

\section{USE OF A SIMULATOR FOR EMERGENCY PROCEDURES TRAINING}

Simulators are an excellent tool to train operators in emergency diagnostics and correct operation in accordance with emergency procedures (Bejger et al., 2018). An example of such actions are the previously-mentioned actions used to diagnose a fire in a scavenge air receiver and the steps taken by the operator of the engine room in the event that such a fire is detected. The following fire simulations in a scavenge air receiver were prepared using Kongsberg MC-90 IV (Kongsberg Maritime, 2005) ship engine room simulator installed in the Maritime University of Szczecin. Basic information about the ship and its propulsion used in the simulator is summarised in Table 1.

Table 1

Ship and engine data used in the experiment

\begin{tabular}{|l|l|}
\hline Parameter & Description \\
\hline Ship type: & tanker \\
Total length: & $305 \mathrm{~m}$ \\
Width: & $47 \mathrm{~m}$ \\
Draught: & $19.7 \mathrm{~m}$ \\
Load capacity: & $187997 \mathrm{DWT}$ \\
\hline Main engine: & MAN B\&W, model 5L90MC \\
Cylinder bore: & $900 \mathrm{~mm}$ \\
Stroke: & $2900 \mathrm{~mm}$ \\
Number of cylinders & 5 \\
Nominal power & $18.4 \mathrm{MW}$ \\
Nominal speed & $74 \mathrm{rpm}$ \\
Nominal mean indicating pressure & $13 \mathrm{bar}$ \\
\hline
\end{tabular}

Source: (Kongsberg Maritime, 2005)

The data of the main engine operation was read for the engine in its full-service condition (reference conditions), and then measurements were made using a simulated fire in the scavenge air receiver. The measurements were made for subsequent machine telegraph settings from $50 \%$ to $100 \%$. Additionally, measurements in the case of a fire in the scavenge air receiver were made for two telegraph settings: $50 \%$ and $100 \%$. During the simulation, the following values were recorded:

- main engine speed [rpm];

- $\quad$ shaft power [MW];

- torque $[\mathrm{kNm}]$

- load indicator [\%];

- exhaust gas temperatures after cylinders [ $\left.{ }^{\circ} \mathrm{C}\right]$;

- average exhaust gas temperature $\left[{ }^{\circ} \mathrm{C}\right]$;

- scavenge air temperature $\left[{ }^{\circ} \mathrm{C}\right]$;

- scavenge air pressure [bar];

- turbochargers speed [rpm];

During the fire simulation, the scavenge air receiver recorded alarms to better illustrate the difference between the reference state and the failure states and the prevailing operating conditions. 


\section{RESULTS AND DISCUSSION}

\subsection{Engine operation under full service condition}

The full service condition served as a reference condition for comparison purposes, and the parameter values are listed in Table 2. Under this condition, the engine was in full working order, and no alarms were reported.

Table 2

Selected engine parameters in the full-service condition

\begin{tabular}{|c|c|c|c|c|c|c|}
\hline $\begin{array}{c}\text { Machine telegraph set- } \\
\text { ting }\end{array}$ & $50 \%$ & $60 \%$ & $70 \%$ & $80 \%$ & $90 \%$ & $100 \%$ \\
\hline Main engine speed [rpm] & 49.22 & 57.72 & 64.00 & 70.30 & 72.15 & 74.00 \\
\hline $\begin{array}{l}\text { Main engine shaft power } \\
{[\mathrm{MW}]}\end{array}$ & 4.44 & 7.42 & 10.37 & 14 & 15.16 & 16.51 \\
\hline Torque $[\mathrm{kNm}]$ & 888.82 & 1255.40 & 1576.50 & 1930.50 & 2035.60 & 2160.50 \\
\hline Load indicator [\%] & 27.84 & 35.01 & 41.35 & 49.49 & 52.78 & 56.62 \\
\hline $\begin{array}{l}\text { Exhaust gas temperature } \\
\text { after cylinder no. } 1\left[{ }^{\circ} \mathrm{C}\right]\end{array}$ & 295.53 & 271.35 & 289.69 & 306.62 & 316.49 & 326.59 \\
\hline $\begin{array}{l}\text { Exhaust gas temperature } \\
\text { after cylinder no. } 2\left[{ }^{\circ} \mathrm{C}\right]\end{array}$ & 261.97 & 273.44 & 291.82 & 309.51 & 319.50 & 328.22 \\
\hline $\begin{array}{l}\text { Exhaust gas temperature } \\
\text { after cylinder no. } 3\left[{ }^{\circ} \mathrm{C}\right]\end{array}$ & 261.69 & 273.39 & 292.39 & 309.86 & 319.25 & 328.00 \\
\hline $\begin{array}{l}\text { Exhaust gas temperature } \\
\text { after cylinder no. } 4\left[{ }^{\circ} \mathrm{C}\right]\end{array}$ & 260.92 & 273.40 & 291.10 & 308.55 & 318.27 & 327.63 \\
\hline $\begin{array}{l}\text { Exhaust gas temperature } \\
\text { after cylinder no. } 5\left[{ }^{\circ} \mathrm{C}\right]\end{array}$ & 259.01 & 271.49 & 288.82 & 306.15 & 316.42 & 325.44 \\
\hline $\begin{array}{l}\text { Average exhaust gas tem- } \\
\text { perature after cylinders }\left[{ }^{\circ} \mathrm{C}\right]\end{array}$ & 260.62 & 272.61 & 290.76 & 308.13 & 317.98 & 327.17 \\
\hline $\begin{array}{l}\text { Scavenge air temperature } \\
{\left[{ }^{\circ} \mathrm{C}\right]}\end{array}$ & 34.79 & 36.97 & 39.55 & 43.63 & 45.26 & 46.72 \\
\hline Scavenge air pressure [bar] & 0.52 & 0.84 & 1.23 & 1.68 & 1.86 & 2.04 \\
\hline $\begin{array}{l}\text { Turbocharger no. } 1 \text { speed } \\
\text { [rpm] }\end{array}$ & 3771.2 & 4843.0 & 5740.5 & 6650.2 & 6981.6 & 7243.9 \\
\hline $\begin{array}{l}\text { Turbocharger no. } 2 \text { speed } \\
\text { [rpm] }\end{array}$ & 3770.9 & 4849.3 & 5737.9 & 6650.5 & 6988.2 & 7250.4 \\
\hline
\end{tabular}

Source: (Strojecki, 2011)

The table shows a clear increase in temperature associated with an increase in the telegraph setting, and thus in the motor speed.

\subsection{Engine operation during fire in scavenge air receiver}

Simulating a fire in the scavenge air receiver in cylinder section No. 2 with the telegraph set to $100 \%$ caused the operator to almost immediately observe an increase in the charge air temperature in the receiver from $46.72^{\circ} \mathrm{C}$ (Table 2) to $116.72^{\circ} \mathrm{C}$ (Fig. 5). 


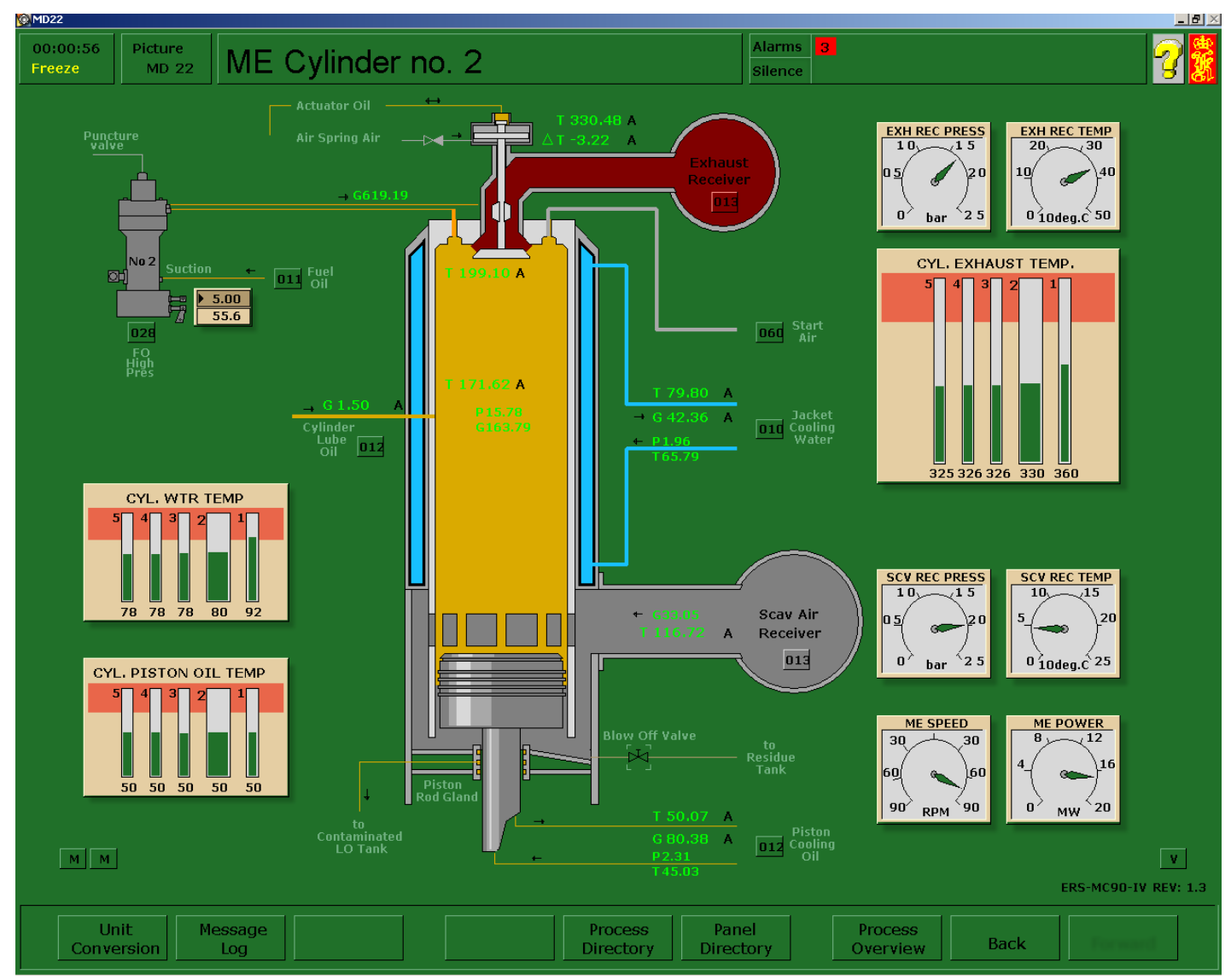

Fig. 5. Operating parameters of subsystems associated with cylinder system No. 2 Source: (Strojecki, 2011)

The operator also observed a high temperature alarm in the receiver and the "slow down" warning alarm (Fig. 6). The heated charge air entering the combustion chamber raised the temperature of the exhaust gases and triggered another alarm for the high exhaust gas temperature. Activation of this alarm caused automatic activation of the "slow down" procedure which caused the motor speed to drop from $74 \mathrm{rpm}$ to 45.3 rpm. High-temperature alarms in the high-temperature exhaust receiver turned off because the temperature equalized and dropped below the alarm threshold. However, the "slow down" alarm was still active because the fire in the receiver was extinguished. The complete list of alarms is shown in Table 3.

Fire in the scavenge air receiver simulated at a 50\% telegraph setting for cylinder No.2 was the same as at the $100 \%$ setting. The only difference was that the "slow down" procedure, which was initiated by the automation system, could not lower the engine speed below its minimum speed, which decreased the revolutions from 49.2 rpm to $44.8 \mathrm{rpm}$ (Table 3).Such a small drop in speed did not significantly change the alarm parameters. Therefore, despite the "slow down", the alarms did not "decrease", but rather gradually increased. 
Table 3

Engine alarm log MAN B\&W-5L90MC during fire in scavenge air receiver

\begin{tabular}{|c|c|c|c|c|}
\hline \multirow{2}{*}{$\begin{array}{l}\text { Speed set- } \\
\text { ting }\end{array}$} & \multicolumn{4}{|r|}{ Alarm } \\
\hline & Time & Value & Sate & Description \\
\hline \multirow{5}{*}{$100 \%$} & 01:32:29 & $116.23^{\circ} \mathrm{C}$ & High & $\begin{array}{l}\text { Main engine Cylinder no. } 2 \text { charge air tem- } \\
\text { perature }\end{array}$ \\
\hline & 01:33:21 & $392.00^{\circ} \mathrm{C}$ & High & $\begin{array}{l}\text { Main engine Cylinder no. } 2 \text { exhaust gas tem- } \\
\text { perature }\end{array}$ \\
\hline & 01:33:35 & $91.75^{\circ} \mathrm{C}$ & High & $\begin{array}{l}\text { Main engine Cylinder no. } 2 \text { cooling water } \\
\text { temperature at outlet }\end{array}$ \\
\hline & 01:33:36 & $47.33^{\circ} \mathrm{C}$ & High & $\begin{array}{l}\text { Main engine Cylinder no. } 2 \text { temperature dif- } \\
\text { ference in the collector and in the combustion } \\
\text { chamber }\end{array}$ \\
\hline & $01: 34: 04$ & $1<0-1>$ & High & Slow Down \\
\hline
\end{tabular}

Source: (Strojecki, 2011)

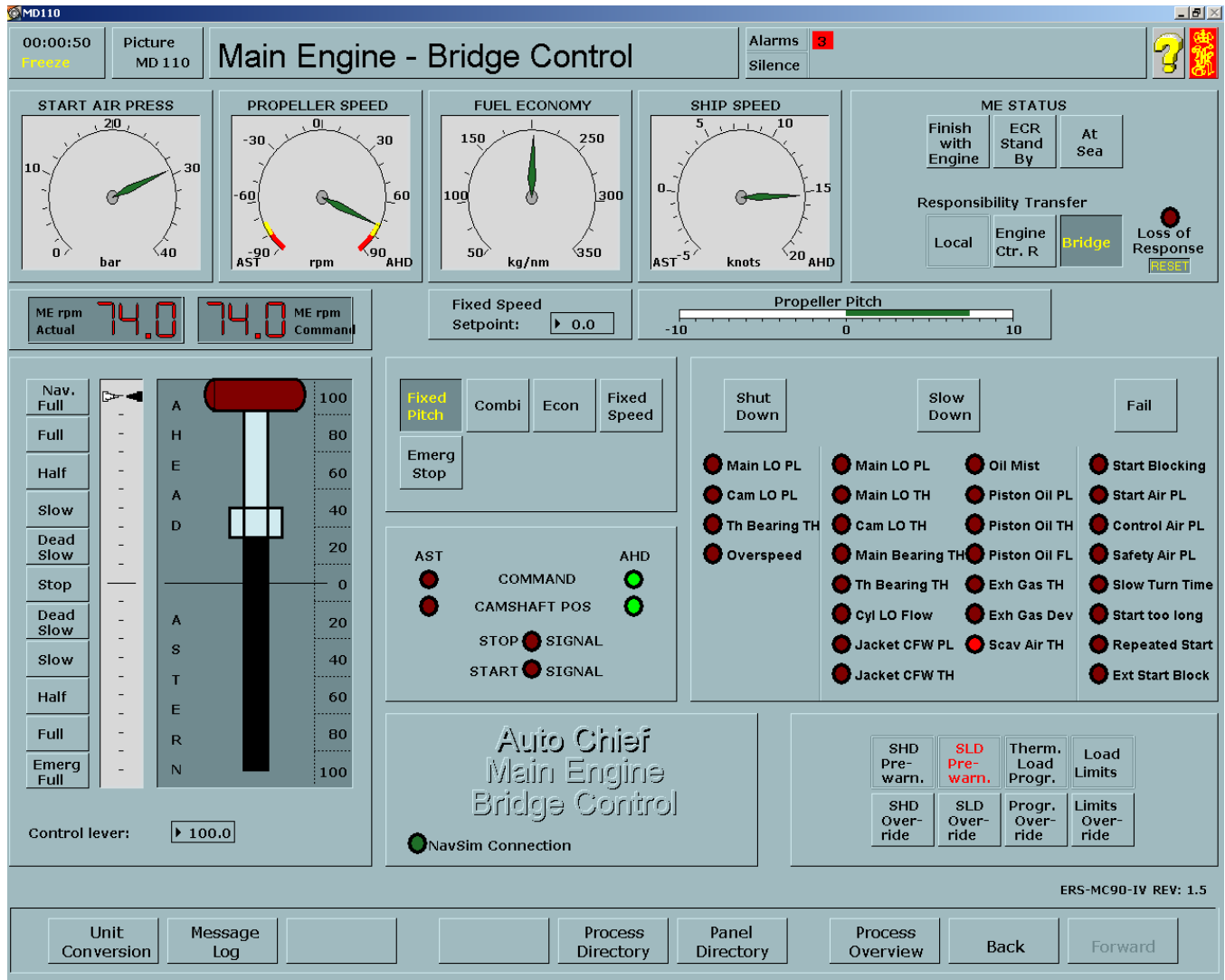

Fig. 6. Bridge drive control station with high-temperature charge air alarm and slow down pre-

Source: (Strojecki, 2011) warning

The next measurement was made with the telegraph set to $100 \%$, and fire was simulated in the entire scavenge air receiver, i.e. in all cylinders. A fire of this magnitude engulfed all engine systems, and there was an immediate increase in the charge air and exhaust temperatures on all cylinders. This caused the automation system to activate the "shut down" procedure due to danger to the motor.

\section{CONCLUSION}

The presented fire scenarios in scavenge air receivers can be successfully used during the training of marine mechanics. Scenarios illustrate to operators of engine room 
causes and effects chain between the occurring situation and the symptoms of the situation. It is possible to analyse processes and their influence for diagnostics, alarm and protection systems.

Complex technical system simulators equipped with appropriate software to simulate emergencies are the cheapest and only safe method to train operators to rapidly respond to life-threatening conditions. In addition, studies regarding the speed of reactions under simulated conditions can be used to obtain valuable data for future analyses of human reliability and can illuminate the origin of disasters.

\section{ACNKOWLEDGMENTS}

The research presented in this article was carried out under the Grant of the Ministry of Science and Higher Education of Poland no 1/S/IESO/17: "Increasing operational effectiveness of complex technical systems by systematic development and implementation of innovations using novel materials and modifying the object's structure" performed at the Maritime University of Szczecin, Poland.

\section{REFERENCES}

Bejger, A., Chybowski, L., Gawdzińska, K., 2018. Utilising elastic waves of acoustic emission to assess the condition of spray nozzles in a marine diesel engine, Journal of Marine Engineering and Technology, DOI: 10.1080/20464177.2018.1492361

Bistrović, M., Ristov, P., Komorčec, D., 2017. Prediction of potential fire hot spots by using a model based on a computerized real - time view with IR cameras on ships, Scientific Journals of the Maritime University of Szczecin, Zeszyty Naukowe Akademii Morskiej w Szczecinie, 50(122), 23-29, DOI: 10.17402/212

Chybowski, L., Gawdzińska, K., Laskowski, R., 2019. Assessing the Unreliability of Systems during the Early Operation Period of a Ship - A Case Study, Journal of Marine Science and Engineering, 7(7), 213:1-12, DOI: 10.3390/jmse7070213

Chybowski, L., Gawdzińska, K., Ślesicki, O., Patejuk, K., Nowosad, G., 2015. An engine room simulator as an educational tool for marine engineers relating to explosion and fire prevention of marine diesel engines, Scientific Journals of the Maritime University of Szczecin, Zeszyty Naukowe Akademii Morskiej w Szczecinie, 43(115), 15-21, DOI: 10.17402/034

Chybowski, L., Kazienko, D., 2019. The Development of an Explosion Protection System in the Starting Air Manifold of a High Power Engine. System Safety: Human - Technical Facility - Environment, 1(1), 26-34, DOI: 10.2478/czoto-20190004

Chybowski, L., Grządziel, Z.,Gawdzińska, K., 2018. Simulation and Experimental Studies of a Multi-Tubular Floating Sea Wave Damper, Energies, 11(4), 1012, DOI: 10.3390/en11041012

Cieślak, A., Jacek, D., Górski, M., Dziubiński, M., Kosmowski, K., Markowski, A., Żyłła, R., 2000. Zapobieganie stratom w przemyśle (Adam S. Markowski, ed.), Łódź.

Gawdzińska, K., Chybowski, L., Nabiałek, M., Szymański, P., 2019. A Study of MetalCeramic Composite Foams Combustibility, Acta Physica Polonica A, 135(2), 304307, DOI: 10.12693/APhysPolA.135.304

Gawdzińska, K., Chybowski, L., Przetakiewicz, W., 2017. Study of Thermal Properties of Cast Metal- Ceramic Composite Foams, Archives of Foundry Engineering, 
17(4), DOI: 10.1515/afe-2017-0129

Gawdzińska, K., Kwiecińska, B., Przetakiewicz, W., Pelczar, M., 2015. Przyczyny wypadków i pożarów na statkach morskich, Zeszyty Naukowe Akademii Morskiej w Gdyni, 91, 21-29.

Kaczyński, P., Ptak, M., A. O. Fernandes, F., Chybowski, L., Wilhelm, J., J. Alves de Sousa, R., 2019. Development and Testing of Advanced Cork Composite Sandwiches for Energy-Absorbing Structures, Materials, 12(5), 697, DOI: 10.3390/ma12050697

Karliński, J., Ptak, M., Chybowski, L., 2019. A Numerical Analysis of the Working Machine Tyre Inflation Process to Ensure Operator Safety, Energies, 12(15), 2971, DOI: 10.3390/en12152971

Karliński, J., Ptak, M., Działak, P., 2014a. Assessment of Safety Cages for Tire Replacement and Inflation, Automotive Safety Conference, Rajeckie Teplice.

Karliński, J., Ptak, M., Działak, P., 2014b. Ocena bezpieczeństwa osłon do pompowania kół, Transport Przemysłowy i Maszyny Robocze, 2, 153-158.

Kongsberg Maritime, 2005. Engine Room Simulator, ERS-L11 MAN B\&W 5L90MCVLCC, Version MC90-IV.

Krystosik-Gromadzińska, A., 2016. Engine room fire safety. Scientific Journals of the Maritime University of Szczecin, Zeszyty Naukowe Akademii Morskiej w Szczecinie, 47(119), 29-35, DOI: 10.17402/145

Krystosik-Gromadzińska, A., 2019. Affordable hybrid thermography for merchant vessel engine room fire safety, Scientific Journals of the Maritime University of Szczecin, Zeszyty Naukowe Akademii Morskiej w Szczecinie, 57(129), 21-26, DOI: $10.17402 / 322$

Laskowski, R., Chybowski, L., Gawdzińska, K., 2015. An engine room simulator as a tool for environmental education of marine engineers, Advances in Intelligent Systems and Computing, 354, DOI: 10.1007/978-3-319-16528-8_29

MAN B\&W Diesel A/S, 2013. MAN B\&W 50-90 MC/MCE Instruction Manual, Copenhagen.

Marine Diesels., 2011. Operational Information Scavenge Fires. Retrieved August 17, 2019,fromhttp://www.marinediesels.info/2_stroke_engine_parts/Other_info/scaven ge_fires.htm

Nozdrzykowski, K., Chybowski, L., 2019. A Force-Sensor-Based Method to Eliminate Deformation of Large Crankshafts during Measurements of Their Geometric Condition, Sensors, 19(16), 3507, DOI: 10.3390/s19163507

Strojecki, S., 2011. Characteristics of methods preventing and extinguishing fires in scavenge areas of low-speed main engines, Maritime University of Szczecin.

Ubowska, A., Szczepanek, M., 2016. Engine rooms fire safety - fire-extinguishing system requirements, Scientific Journals of the Maritime University of Szczecin, Zeszyty Naukowe Akademii Morskiej w Szczecinie, 48(120), 51-57, DOI: $10.17402 / 175$

Ulewicz, R.,Mazur, M., 2013. Fatigue Testing Structural Steel as a Factor of Safety of Technical Facilities Maintenance, Production Engineering Archives, 1/1, 32-34, DOI: 10.30657/pea.2013.01.10

Ulewicz, R., Nový, F., Novák, P., Palček, P., 2019. The investigation of the fatigue failure of passenger carriage draw-hook, Engineering Failure Analysis, 104, 609616, DOI: 10.1016/j.engfailanal.2019.06.036 